\title{
Male Central Hypogonadism in Paediatrics - the Relevance of Follicle-stimulating Hormone and Sertoli Cell Markers
}

\author{
Romina P Grinspon, ${ }^{1}$ Mariela Urrutia' ${ }^{1}$ and Rodolfo A Rey ${ }^{1,2}$
}

1. Centro de Investigaciones Endocrinológicas "Dr. César Bergadá" (CEDIE), National Scientific and Technical Research Council (CONICET) - Fundación de Endocrinología Infantil (FEI) - División de Endocrinología, Hospital de Niños Ricardo Gutiérrez, Buenos Aires, Argentina; 2. Departamento de Histología, Biología Celular, Embriología y Genética, Facultad de Medicina, Universidad de Buenos Aires, Buenos Aires, Argentina

DOl: https://doi.org/10.17925/EE.2018.14.2.67

$\mathrm{T}$ he definition of male hypogonadism, used in adult endocrinology, is not fully applicable to paediatrics. A clear understanding of the developmental physiology of the hypothalamic-pituitary-testicular axis is essential for the comprehension of the pathogenesis of hypogonadal states in boys and for the establishment of adequate definitions and classifications in paediatric ages. This is particularly true for central hypogonadism, usually called hypogonadotropic in adults. Because childhood is a period characterised by a physiological state of low gonadotropin and testosterone production, these markers of hypogonadism, typically used in adult endocrinology, are uninformative in the child. This review is focused on the physiological importance of prepubertal Sertoli cell markers - anti-Müllerian hormone (AMH) and inhibin B - and of the intratesticular actions of follicle-stimulating hormone (FSH) and testosterone during early infancy and the first stages of pubertal development. We discuss the role of FSH in regulating the proliferation of Sertoli cells - the main determinant of prepubertal testicular volume - and the secretion of AMH and inhibin B. We also address how intratesticular testosterone concentrations have different effects on the seminiferous tubule function in early infancy and during pubertal development.

\section{Keywords}

Micropenis, microorchidism, cryptorchidism, puberty, hCG, human chorionic

gonadotropin, recombinant human FSH

Disclosure: Romina P Grinspon and Rodolfo A Rey have received honoraria from CONICET (Argentina) for technology services using the Anti-Müllerian Hormone (AMH) ELISA. Rodolfo A Rey has received royalties derived from an agreement between Inserm (France) and Beckman-Coulter-Immunotech for the development of the AMH ELISA. Mariela Urrutia has no conflicts of interest to disclose.

Review Process: Double-blind peer review

Authorship: All named authors meet the criteria of the International Committee of Medical Journal Editors for authorship for this manuscript, take responsibility for the integrity of the work as a whole and have given final approval for the version to be published.

open Access: This article is published under the Creative Commons Attribution Noncommercial License, which permits any non-commercial use, distribution, adaptation and reproduction provided the original author(s) and source are given appropriate credit. (C) The Authors 2018 .

Received: 17 May 2018

Accepted: 02 July 2018

Citation: European Endocrinology, 2018;14(2):67-71

Corresponding Author: Rodolfo A Rey, MD, PhD, Director, Centro de Investigaciones Endocrinológicas "Dr. César Bergadá" (CEDIE), CONICET - FEI División de Endocrinología, Hospital de Niños Ricardo Gutiérrez, Gallo 1330, C1425EFD Buenos Aires, Argentina. E: rodolforey@cedie.org.ar

Funding: This work was partially funded by PIP grant \#11220130100687 of CONICET (Consejo Nacional de Investigaciones Científicas y Técnicas) and PICT grants \#2014-2490 and \#2016-0993 of FONCYT (Fondo para la Investigación Científica y Tecnológica), Argentina.
In the adult male, hypogonadism is usually defined by the failure of the testis to produce physiological concentrations of testosterone and/or a normal number of spermatozoa. ${ }^{1}$ When due to abnormalities of the hypothalamic-pituitary axis, the condition is referred to as hypogonadotropic or central hypogonadism, whereas those due to testicular defects are called hypergonadotropic or primary hypogonadism. However, these definitions are inadequate for most paediatric conditions. Indeed, during the largest part of infancy and childhood, the hypothalamicgonadotroph axis is quiescent and the testes produce neither spermatozoa nor detectable amounts of testosterone. A more adapted definition and classification of male hypogonadism is based on the developmental physiology of the gonadal axis. ${ }^{2}$ Accordingly, the definition should be extended to any decreased testicular function as compared to what is expected for age, involving impaired hormone secretion by Leydig cells (i.e., androgens, insulin-like 3 [INSL3]), Sertoli cells (i.e., anti-Müllerian hormone [AMH], inhibin B) and/or a disorder of spermatogenesis. Moreover, it should be emphasised that primary hypogonadism rarely presents with elevated gonadotropin levels ${ }^{3}$ and even anorchidism might present with normal gonadotropin levels in about 30-60\% of the cases during childhood ${ }^{4}$ indicating that the term hypergonadotropic hypogonadism may be misleading in paediatrics. Additionally, since circulating gonadotropin concentrations are low in the normal prepubertal boy, it is difficult to demonstrate the existence of levels below normal, thus making the term hypogonadotropic hypogonadism also inadequate.

A clear understanding of the developmental physiology of the hypothalamic-pituitary-testicular axis is essential for the comprehension of the pathogenesis of hypogonadal states in paediatric ages (Figure 1). Under hypothalamic control, the gonadotrophs secrete luteinizing hormone (LH) and follicle-stimulating hormone (FSH) during the second and third trimesters of foetal life, and also during the first 3-6 months after birth - a period usually referred to as mini-puberty. ${ }^{5,6} \mathrm{LH}$ induces Leydig cell activation, resulting in testosterone production at levels that are similar to those of the adult. Androgens are responsible for testicular descent and penile growth. FSH induces Sertoli cell proliferation? and since Sertoli cells represent the largest part of testicular mass before puberty, FSH is the main factor regulating testicular volume (Figure 2). Sertoli cells produce peptide hormones, such as inhibin B and AMH. Although their basal production is gonadotropin-independent, there is clinical ${ }^{8-10}$ and experimental evidence ${ }^{11,12}$ that FSH increases Sertoli cell secretion of inhibin $\mathrm{B}$ and $\mathrm{AMH}$.

Around birth, there is a transient decrease in gonadotropin and testicular hormone levels, ${ }^{13}$ but from the second week of postnatal life, all hormone levels increase and remain high for 3-6 months. ${ }^{6}$ 
Figure 1: Serum levels of reproductive axis hormones in the male

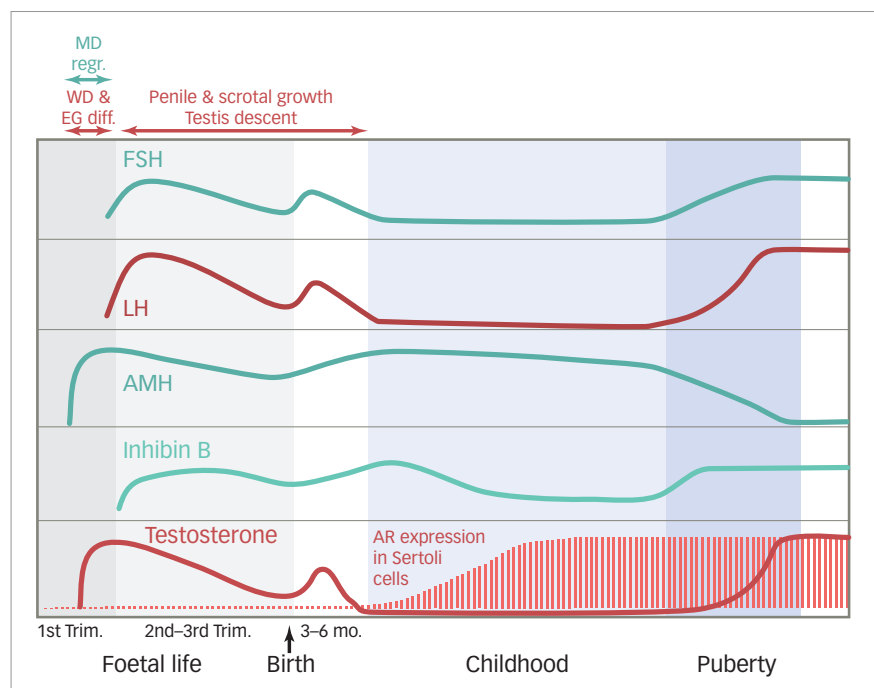

Schematic of the ontogeny of serum levels of reproductive axis hormones from foetal life through adulthood and its association with physiological events of the reproductive tract development. $A M H=$ anti-Müllerian hormone; $A R=$ androgen receptor: $F S H=$ follicle-stimulating hormone: $L H=$ luteinizing hormone: $M D$ regr = regression of Müllerian ducts (anlagen of the uterus and Fallopian tubes) occurring in response to $A M H ; m o=$ months; Trim = trimester of foetal life; WD \& EG diff = differentiation of Wolffian ducts (anlagen of the epididymis, vas deferens and seminal vesicles) and external genitalia, occurring in response to testosterone. Modified with permission from Grinspon et al. 2014.28

Thereafter and during the rest of infancy and childhood, LH and testosterone decrease to very low or undetectable levels. FSH and inhibin B also decrease but remain clearly detectable. ${ }^{14}$ Conversely, $\mathrm{AMH}$ peaks in the first year and remains high during childhood ${ }^{15,16}$ until it decreases in puberty inhibited by testosterone. ${ }^{17}$ In spite of the high levels of testosterone that seminiferous cords are exposed to during the foetal and postnatal periods, no signs of maturation are observed in Sertoli and germ cells. This is explained by the fact that Sertoli cells are physiologically insensitive to testosterone because the androgen receptor is not expressed in Sertoli cells until the second year of postnatal life (Figure 1). ${ }^{18}$ In fact, when elevated androgen levels abnormally persist beyond the age of 1 year (e.g. in boys with central precocious puberty), clear signs of Sertoli cell maturation appear. ${ }^{19}$

The onset of puberty is characterised by the increase in gonadotropin pulse frequency and amplitude. FSH further boosts testicular volume to $>4$ Cc (Figure 2). LH reawakens Leydig cell activity, leading initially to an increase in intratesticular testosterone concentration which provokes Sertoli cell maturation: they stop dividing and decrease their expression of AMH. ${ }^{5}$ Mature sertoli cells are able to sustain spermatogenesis:20 the completion of this process leads to sperm production and also results in the remarkable increase of testicular volume to $15-25 \mathrm{cc}$. The elevation of serum testosterone and the resulting development of secondary sexual characteristics is a relatively late event in boys.

\section{Central hypogonadism in boys \\ Aetiology}

\section{Congenital central hypogonadism}

congenital central ("hypogonadotropic") hypogonadism reflects the failure of the pituitary to produce sufficient amounts of gonadotropins. Most frequently, it is caused by deficient production, secretion or action of gonadotropin-releasing hormone $(\mathrm{GnRH}){ }^{21}$ The condition can be isolated and it is known as isolated hypogonadotropic hypogonadism, ${ }^{22}$
Figure 2: Schematic representation of the association between testicular volume and hormonal changes during postnatal development

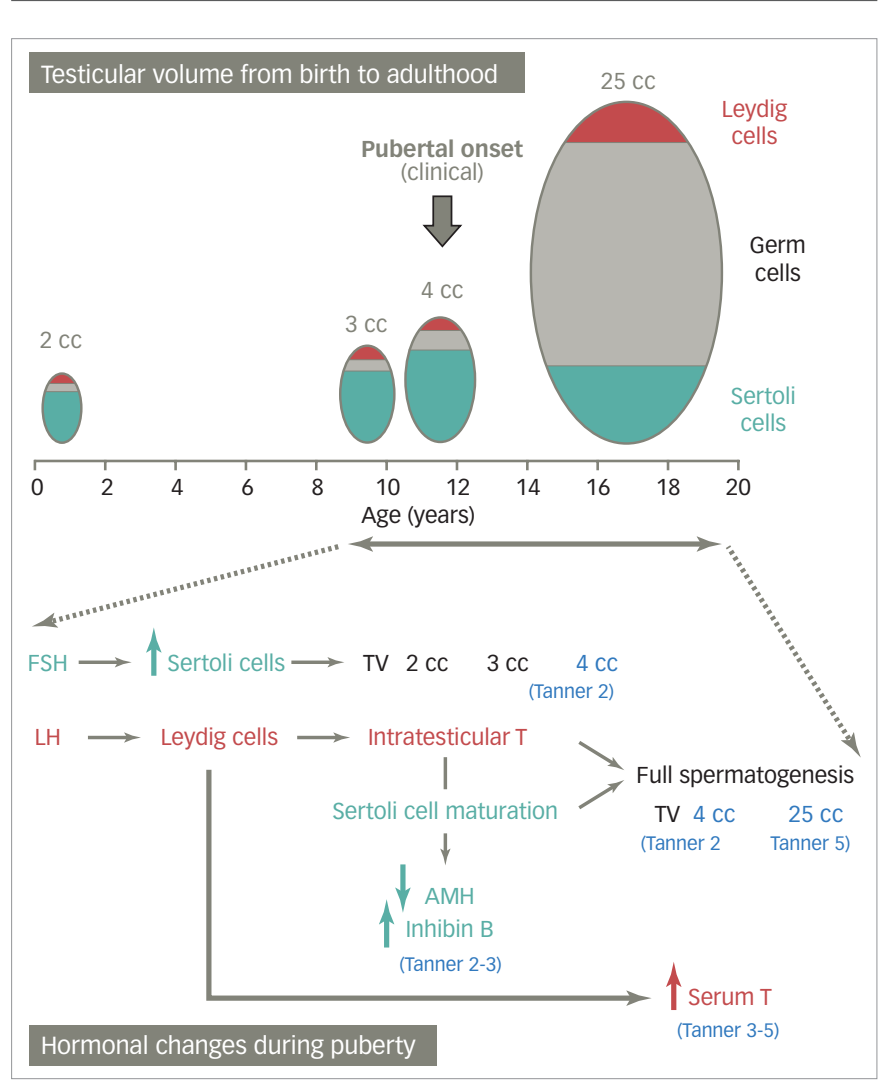

During infancy and childhood, there is little change in testicular volume, which depends mainly on Sertoli cell number. From a clinical standpoint, when testicular volume reaches $4 \mathrm{cc}$ the boy is said to have started pubertal development (Tanner stage two). This is due mainly to Sertoli cell proliferation in response to increased FSH activity. Concomitantly, LH induces Leydig cell testosterone secretion, resulting in an increase in intratesticular testosterone concentration. This leads to Sertoli cell maturation (reflected by a decrease in $\mathrm{AMH}$ secretion and an increase in inhibin B, during Tanner stages two to three) and the development of full adult spermatogenesis, the main responsible for testicular volume growth between pubertal Tanner stages two to five. Subsequently, testosterone also increases in serum (Tanner stages three to five). $A M H=$ anti-Müllerian hormone; $F S H=$ follicle-stimulating hormone; $\mathrm{LH}=$ luteinizing hormone; $T$ = testosterone; $T V=$ testicular volume. Modified with permission from Edelsztein et al., 2016. ${ }^{31}$

or associated to other pituitary hormone deficiencies. ${ }^{23}$ Several gene defects have been described as the cause of gonadotropin insufficiency. The pathogenesis may be related to: 1) altered GnRH neuron formation in the olfactory placode or its migration to the hypothalamus (usually associated with hyposmia/anosmia and known as Kallmann syndrome), 2) abnormal GnRH production due to defects in regulatory factors or in the GnRH1 gene, and 3) defective action in the gonadotroph owing to abnormalities in the $\mathrm{GnRH}$ receptor or its transduction pathway. ${ }^{21,22}$ Extremely rare are mutations in the genes encoding the beta subunits of $\mathrm{LH}$ or FSH. ${ }^{24}$ Finally, genes associated with defective formation of the hypothalamic-pituitary region have been described in a low proportion of cases with multiple pituitary hormone deficiency. ${ }^{25}$

\section{Acquired central hypogonadism}

Of all paediatric and pubertal forms of central hypogonadism, approximately $20 \%$ are of functional origin. In these cases, a chronic illness or an underlying stressor causes the suppression of gonadotropin secretion and the condition can be reverted when the chronic illness is adequately treated. ${ }^{26}$ Conversely, permanent forms are due to conditions affecting the hypothalamic-pituitary area, e.g. high radiation doses, tumours, infections, surgery, etc. 


\section{Clinical presentation Neonatal and infancy}

The insufficiency of $\mathrm{LH}$ and testosterone during the second half of foetal life usually results in micropenis, cryptorchidism and hypoplastic scrotum. On the other hand, FSH insufficiency leads to microorchidism due to Sertoli cell hypoplasia. Midline defects and signs like hypoglycaemia or jaundice can orientate to multiple pituitary hormone deficiencies. Unfortunately, the insufficient attention given to cardinal features, such as micropenis, cryptorchidism, cleft lip/palate, deafness, coloboma, etc. in the newborn or infant results in missing the window of opportunity for the diagnosis during the postnatal activation period.

\section{Prepubertal age}

Since changes in testicular volume and penile size are minimal during childhood, acquired central hypogonadism established in this period of life may go underdiagnosed even if the underlying aetiology is evident, e.g. tumours or surgery of the central nervous system.

\section{Pubertal age}

Absence of pubertal signs is the main feature of complete forms of central hypogonadism, whereas delayed onset or progression, or even arrest of pubertal development, may be indicative of partial forms. At this age, smell testing can be helpful if a congenital form (Kallmann syndrome) is suspected.

\section{Hormonal laboratory testing Gonadotropins and testosterone}

The window of opportunity for confirming central hypogonadism using gonadotropin and testosterone measurements in term newborns and infants resides between the third week and the third month. Indeed, in the first 2 weeks, gonadotropins and testosterone may still be low and only starting to increase after the perinatal nadir in normal newborns, ${ }^{13}$ thus hormone values should be interpreted cautiously in order to avoid false positive diagnoses. Similarly, from the fourth to sixth month onwards, gonadotropins and testosterone may already be decreasing physiologically. During the post-natal active period, or mini-puberty, low LH and testosterone have high positive predictive values for central hypogonadism. ${ }^{23,27-29}$

If the diagnosis was not certified before the sixth month of age, LH and testosterone levels are no longer informative until pubertal age. Although FSH is usually neglected in the study of male central hypogonadism, circulating levels never drop to undetectable during childhood and can therefore be more informative than LH. Indeed, in a series of boys presenting without spontaneous pubertal development, basal FSH had a higher predictive value than LH for the diagnosis of central hypogonadism. ${ }^{30}$

\section{Sertoli cell markers}

As already mentioned, AMH and inhibin B are sertoli cell products, whose basal production is independent of gonadotropins. Nevertheless, FSH is capable of increasing inhibin $\mathrm{B}^{8.9}$ and $\mathrm{AMH}^{9,10}$ testicular secretion, thus indicating that they both are good markers of FSH action on the testis. ${ }^{31}$ The increased $\mathrm{AMH}$ testicular output in response to FSH in prepubertal male patients reflects two effects of FSH on immature Sertoli cells. On one hand, FSH induces Sertoli cell proliferation, ${ }^{7}$ which explains that FSH treatment in newborns or infants causes an increase in testicular volume. ${ }^{9}$ $\mathrm{AMH}$ levels reflect the amount of functional sertoli cells in different conditions. ${ }^{32-34}$ On the other hand, using two experimental models, knockout mice null for the gene encoding the FSH beta subunit' ${ }^{12}$ and the prepubertal Sertoli cell lineage SMAT1 expressing $\mathrm{AMH}^{35}$ we showed that FSH upregulates the AMH promoter activity signalling through the cyclic AMP-mediated pathway, mainly via protein kinase A activity. ${ }^{36,37}$
The aforementioned regulation of Sertoli cells by FSH during foetal life and the neonatal period explains the findings of microorchidism and low serum $\mathrm{AMH}$ and inhibin B in boys with congenital central hypogonadism. 8,9,23,29,38

\section{Treatment}

\section{Testosterone}

In patients with congenital central hypogonadism, the presence of micropenis may prompt testosterone treatment. When the diagnosis is made at birth - or more rarely during childhood - depot testosterone (testosterone enanthate or cypionate) at 25-50 $\mathrm{mg} /$ dose intramuscular (IM) every 4 weeks for 3 consecutive months may be sufficient to normalise penile size without provoking an advancement of bone age. ${ }^{39}$ In older boys with central hypogonadism reaching the age of puberty, steroid replacement is necessary for the development of secondary sex characteristics, the acquisition of full bone mass and the optimisation of height velocity, as well as for avoiding psychosocial distress. Depot testosterone is given at $50 \mathrm{mg} \mathrm{IM}$ each month for 6-12 months, with a subsequently progressive dose escalation until a full dose of $250 \mathrm{mg} /$ month in 2-3 years. The aim is to mimic normal pubertal tempo. When full pubertal development is attained, treatment should be switched to follow standards for adults. ${ }^{1}$ Alternative approaches include oral androgens such as testosterone undecanoate ${ }^{40}$ and transdermal gels. .1,42 $^{4,2}$

\section{Gonadotropins}

Exogenous testosterone supplementation aims to attain physiological circulating androgen levels. However, physiological intratesticular testosterone concentration is never reached with these treatments, whose disadvantages are that sertoli cells neither proliferate nor mature and, subsequently, adult spermatogenesis does not develop. In fact, testicular volume remains small $(<4 \mathrm{cc})$ in patients receiving only testosterone treatment.

Treatment with pulsatile GnRH or combined gonadotropins is well established in adult patients with central hypogonadism seeking fertility. ${ }^{21}$ Conversely, limited information is available on the use of gonadotropins in paediatric patients. ${ }^{43}$ Observational studies on infants with congenital central hypogonadism suggest that the postnatal peak in reproductive hormones plays an important role in genital development. ${ }^{44}$ Therefore, various authors have proposed the use of gonadotropins during infancy, instead of testosterone, to mimic mini-puberty in patients with congenital central hypogonadism. A case report describes an infant treated from the age of 7.9 months with recombinant human (rh) LH (subcutaneous injections $20 \mathrm{IU}$ twice a week) and FSH (subcutaneous injections $2.5 \mathrm{IU} / \mathrm{kg}$ twice a week). ${ }^{45}$ Testicular volume increased $170 \%$, reflecting FSH action on Sertoli cells.

A case series reports eight patients aged $0.25-11$ months who received continuous infusion of rhLH and rhFSH with insulin pumps at a daily rate of 50 and 75-150 IU, respectively." Testicular hormones reached "minipuberty" levels, complete testis descent occurred in six patients and partial descent in two, and testes and penis reached normal dimensions in all cases. Similar results were observed in patients receiving continuous subcutaneous infusion of rh gonadotropins. ${ }^{46}$ Even though long-term follow-up is needed to fully evaluate the outcomes of this therapeutic approach, these results suggest that subcutaneous gonadotropin infusion is able to induce not only Sertoli cell proliferation and function but also testis descent in patients with congenital central hypogonadism, thus avoiding surgical treatment. ${ }^{47}$

Only one study reports prepubertal treatment with rhFSH of three boys with central hypogonadism. ${ }^{8}$ In this case, the rationale was that 
Figure 3: Effect of sequential rhFSH and hCG treatment on $\mathrm{AMH}$ and testosterone in patients with central hypogonadism

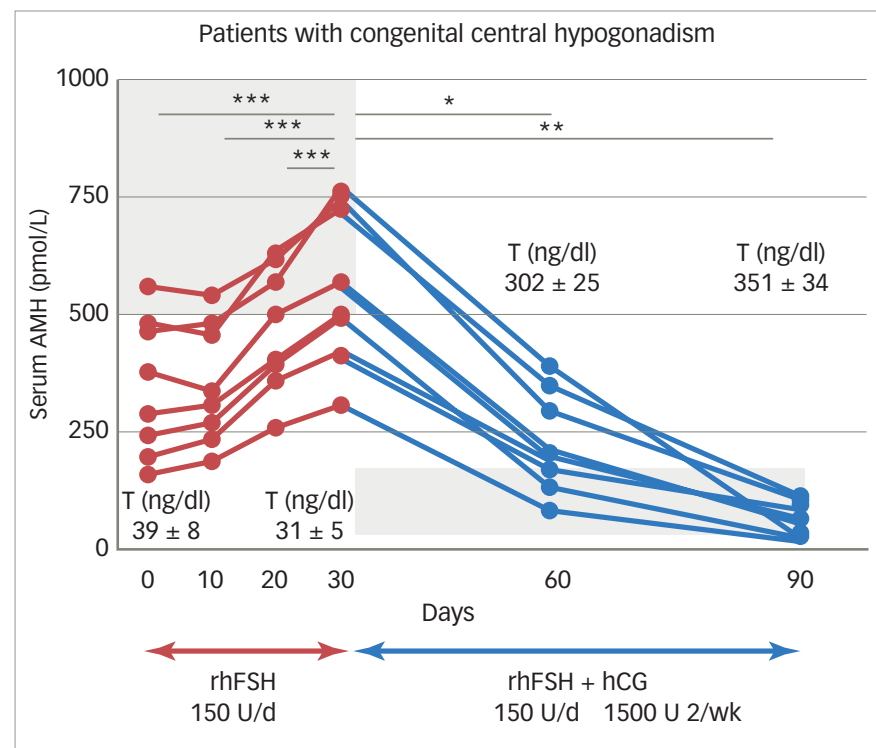

Initial treatment with rhFSH for 30 days provoked an elevation of serum AMH, while testosterone remained at prepubertal levels. Shaded area represents normal $\mathrm{AMH}$ levels for boys with low testosterone (corresponding to pubertal Tanner stage one). subsequent addition of hCG induced an elevation of $T$, which provoked a decline in serum AMH. Shaded area represents normal AMH values for Tanner stages 4-5, according to the Tlevels observed in the treated patients. ${ }^{*} p<0.05$; ${ }^{*} p<0.01$; $* * * p<0.001 . A M H=$ anti-Müllerian hormone; $h C G=$ human chorionic gonadotropin rhFSH = recombinant human follicle-stimulating hormone: $T$ = testosterone. Modified with permission from Young et al., 2005. ${ }^{10}$

FSH would be capable of inducing Sertoli cell multiplication before they mature at puberty. The boys were given rhFSH subcutaneously $(1.5 \mathrm{IU} / \mathrm{kg})$ three times a week for 12 months. Treatment induced testicular growth and inhibin B production, reflecting stimulation of immature Sertoli-cell function. These findings suggest that FSH treatment in childhood is capable of inducing Sertoli-cell proliferation, which may result in an increased sperm-producing capacity in adulthood.

Finally, several publications exist on combined recombinant gonadotropin treatment for the induction of puberty in boys with central hypogonadism. Some of them used the standard protocols for adults initiating with human chorionic gonadotropin (hCG) and then adding rhFSH ${ }^{48,49}$ and showed acceptable results. Moreover, in studies using initial priming with rhFSH prior to induction of puberty with the combination of rhFSH and hCG, rhFSH induced prepubertal testicular growth and increased serum levels of $\mathrm{AMH}$ (Figure 3) 3) $^{10}$ and inhibin B levels (Figure 4), ${ }^{10,50}$ confirming the importance of FSH action on immature Sertoli cells. The addition of hCG resulted in a progressive increase in testosterone production, Sertoli cell maturation suggested by an important decrease in serum $\mathrm{AMH}$ and acquisition of sperm production. ${ }^{10}$ Also, the increase of inhibin B proved useful for monitoring spermatogenic development. ${ }^{50}$ More recently, an openlabel randomised study in hypogonadal males aged $>18$ years showed better results in men receiving rhFSH pre-treatment in terms of spermatogenic development. ${ }^{51}$

\section{Concluding remarks}

While LH and testosterone levels have been used for years in the diagnosis of central hypogonadism at pubertal age and adulthood, in paediatric
Figure 4: Effect of sequential rhFSH and hCG treatment on inhibin $B$ and testicular volume in patients with central hypogonadism

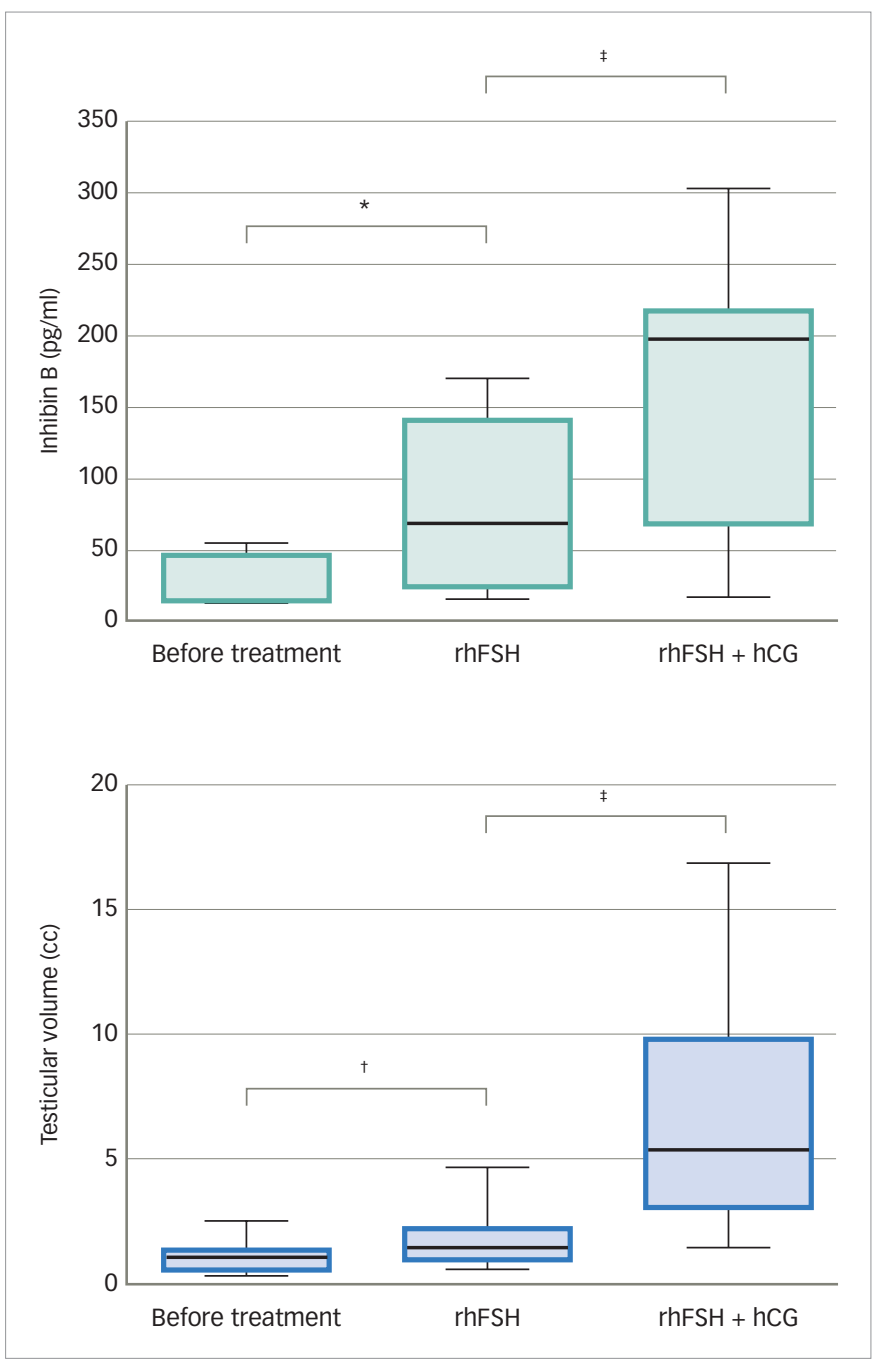

Effect of rhFSH and FSH plus hCG treatments on serum inhibin B levels (top) and testis volume (bottom) in boys with prepubertal onset of gonadotropin deficiency. ${ }^{*} p<0.01$; $t p<0.005 ; \neq p<0.001$. FSH = follicle-stimulating hormone; $h C G=$ human chorionic gonadotropin; rhFSH = recombinant human follicle-stimulating hormone. Modified with permission from Raivio et al., 2007.50

patients they are useful only during the early post-natal activation period. During childhood, low levels of the sertoli cell markers AMH and inhibin B support the diagnosis of central hypogonadism. Furthermore, although testosterone replacement therapies have been used for many years with satisfactory results on the development of secondary sex characteristics in adolescents with central hypogonadism, more recently the attention has been driven to the physiological importance of the intratesticular actions of FSH and testosterone during early infancy and the first stages of pubertal development.

The limited number of studies available to date demonstrate that a sequential treatment approach with rhFSH priming to induce Sertoli cell proliferation, before adding hCG or rhLH to provoke an increase in intratesticular testosterone concentration and Sertoli cell maturation, shows encouraging results in terms of induction of testicular growth and sperm production..$^{8,0,50,51}$ To definitively prove the superiority of this approach, larger randomised prospective studies are necessary. $\square$ 
1. Bhasin S, Brito JP, Cunningham GR, et al. Testosterone therapy in men with hypogonadism: an endocrine society clinical practice guideline J Clin Endocrinol Metab. 2018,103:1-30.

2. Rey RA, Grinspon RP, Gottlieb S, et al. Male hypogonadism: an extended classification based on a developmental, endocrine physiology-based approach. Andrology. 2013;1:3-16.

3. Grinspon RP, Gottlieb S, Bedecarras P, Rey RA. Anti-Müllerian hormone and testicular function in prepubertal boys with cryptorchidism. Front Endocrinol (Lausanne). 2018;9:182.

. Grinspon RP, Ropelato MG, Bedecarrás P, et al. Gonadotrophi secretion pattern in anorchid boys from birth to pubertal age: pathophysiological aspects and diagnostic usefulness. Clin Endocrinol (Oxf). 2012;76:698-705.

5. Rey RA. Mini-puberty and true puberty: differences in testicular function. Ann Endocrinol (Paris). 2014;75:58-63.

6. Kuiri-Hänninen T, Sankilampi U, Dunkel L. Activation of the hypothalamic-pituitary-gonadal axis in infancy, minipuberty. Horm Res Paediatr. 2014;82:73-80.

7. Orth JM. The role of follicle-stimulating hormone in controlling Sertoli cell proliferation in testes of fetal rats. Endocrinology. 1984;115:1248-55.

8. Raivio T Toppari J, Perheentupa A, et al. Treatment of prepubertal gonadotrophin-deficient boys with recombinant human follicle-stimulating hormone. Lancet. 1997;350:263-4

9. Lambert AS, Bougnères P. Growth and descent of the testes in infants with hypogonadotropic hypogonadism receiving subcutaneous gonadotropin infusion. Int J Pediatr Endocrinol. 2016;2016:13.

10. Young J, Chanson P, Salenave S, et al. Testicular anti-Müllerian hormone secretion is stimulated by recombinant human FSH in patients with congenital hypogonadotropic hypogonadism. J Clin Endocrinol Metab. 2005;90:724-8.

11. Al-Attar L, Noël K, Dutertre M, et al. Hormonal and cellular regulation of Sertoli cell anti-Müllerian hormone production in the postnatal mouse. J Clin Invest. 1997:100:1335-43.

12. Lukas-Croisier C, Lasala C, Nicaud J, et al. Follicle-stimulating hormone increases testicular Anti-Müllerian hormone (AMH) production through sertoli cell proliferation and a nonclassical cyclic adenosine 5 '-monophosphate-mediated activation of the AMH gene. Mol Endocrinol. 2003;17:550-61.

13. Bergadá I, Milani C, Bedecarrás P, et al. Time course of the serum gonadotropin surge, inhibins, and anti-Mullerian hormone in normal newborn males during the first month of life. J Clin Endocrinol Metab. 2006;91:4092-8.

14. Andersson AM, Toppari J, Haavisto AM, et al. Longitudinal reproductive hormone profiles in infants: peak of inhibin $B$ levels in infant boys exceeds levels in adult men. J Clin Endocrinol Metab. 1998;83:675-81.

15. Grinspon RP, Bedecarrás P, Ballerini MG, et al. Early onset of primary hypogonadism revealed by serum anti-Müllerian primary hypogonadism revealed by serum anti-Mullerian trisomy 21. Int J Androl. 2011;34:e487-98.

16. Aksglæde $L$ Sorensen $K$ Boas $M$, et al. Changes in anti-Müllerian hormone (AMH) throughout the life span: a population-based hormone (AMH) throughout the life span: a population-based
study of 1027 healthy males from birth (cord blood) to the age of study of 1027 healthy males from birth (cord blood)

69 years. J Clin Endocrinol Metab. 2010;95:5357-64.
17. Rey R, Lordereau-Richard I, Carel JC, et al. Anti-Müllerian hormone and testosterone serum levels are inversely related during normal and precocious pubertal development. J Clin Endocrinol Metab. 1993;77:1220-6.

18. Chemes HE, Rey RA, Nistal M, et al. Physiological androgen insensitivity of the fetal, neonatal, and early infantile testis is explained by the ontogeny of the androgen receptor expression in Sertoli cells. J Clin Endocrinol Metab. 2008;93:4408-12.

19. Grinspon RP, Andreone L, Bedecarrás P, et al. Male central precocious puberty: serum profile of anti-Mullerian hormone
and inhibin B before, during, and after treatment with GnRH analogue. Int J Endocrinol. 2013:2013:823064.

20. França LR, Hess RA, Dufour JM, et al. The Sertoli cell: one hundred fifty years of beauty and plasticity. Andrology. 2016;4:189-212.

21. Boehm U, Bouloux PM, Dattani MT, et al. Expert consensus document: European Consensus Statement on congenital hypogonadotropic hypogonadism--pathogenesis, diagnosis and treatment. Nat Rev Endocrinol. 2015;11:547-64.

22. Lima Amato LG, Latronico AC, Gontijo Silveira LF. Molecular and genetic aspects of congenital isolated hypogonadotropic hypogonadism. Endocrinol Metab Clin North Am. 2017:46:283-303

23. Braslavsky D, Grinspon RP, Ballerini MG, et al. Hypogonadotropic hypogonadism in infants with congenital hypopituitarism: a challenge to diagnose at an early stage. Horm Res Paediatr. 2015;84:289-97.

24. Valdes-Socin $\mathrm{H}$, Rubio Almanza M, Tomé Fernández-Ladreda $\mathrm{M}$, et al. Reproduction, smell, and neurodevelopmental disorders: genetic defects in different hypogonadotropic hypogonada syndromes. Front Endocrinol (Lausanne). 2014;5:109.

25. Castinetti F, Reynaud R, Quentien MH, et al. Combined pituitary hormone deficiency: current and future status. I Endocrinol Invest. 2015;38:1-12

26. Palmert MR, Dunkel L. Clinical practice. Delayed puberty. N Engl J Med. 2012;366:443-53.

27. Grumbach MM. A window of opportunity: the diagnosis of gonadotropin deficiency in the male infant. I Clin Endocrino Metab. 2005;90:3122-7.

28. Grinspon RP, Loreti N, Braslavsky D, et al. Spreading the clinical window for diagnosing fetal-onset hypogonadism in boys. Front Endocrinol (Lausanne). 2014;5:51.

29. Vizeneux A, Hilfiger A, Bouligand J, et al. Congenital hypogonadotropic hypogonadism during childhood: presentation and genetic analyses in 46 boys. PLOS One. 2013;8:e77827.

30. Grinspon RP, Ropelato MG, Gottlieb S, et al. Basal folliclestimulating hormone and peak gonadotropin levels after gonadotropin-releasing hormone infusion show high diagnostic accuracy in boys with suspicion of hypogonadotropic hypogonadism. J Clin Endocrinol Metab. 2010;95:2811-8.

31. Edelsztein NY, Grinspon RP, Schteingart HF, Rey RA. Anti-Müllerian hormone as a marker of steroid and gonadotropin action in the testis of children and adolescents with disorders of the gonada axis. Int J Pediatr Endocrinol. 2016;2016:20.

32. Rey R, Al-Attar L, Louis F, et al. Testicular dysgenesis does not affect expression of anti-mullerian hormone by Sertoli cells in premeiotic seminiferous tubules. Am J Pathol. 1996;148:1689-98.

33. Grinspon RP, Habib C, Bedecarrás P, et al. Compensatory function of the remaining testis is dissociated in boys and adolescents with monorchidism Eur J Endocrinol. 2016;174:399-407.

34. Rey RA, Venara M, Coutant R, et al. Unexpected mosaicism of R201H-GNAS1 mutant-bearing cells in the testes underlie macro-orchidism without sexual precocity in McCune-Albright syndrome. Hum Mol Genet. 2006;15:3538-43.

35. Dutertre M, Rey R, Porteu A, et al. A mouse Sertoli cell line expressing anti-Müllerian hormone and its type II receptor. Mol Cell Endocrinol. 1997;136:57-65.

36. Lasala C, Carré-Eusèbe D, Picard JY, Rey R. Subcellular and molecular mechanisms regulating anti-Müllerian hormone gene expression in mammalian and nonmammalian species DNA Cell Biol. 2004:23:572-85.

37. Lasala C, Schteingart HF, Arouche $\mathrm{N}$, et al. SOX9 and SF are involved in cyclic AMP-mediated upregulation of anti-Müllerian gene expression in the testicular prepubertal Sertoli cell line SMAT1. Am J Physiol Endocrinol Metab. 2011;301:E539-47.

38. Grinspon RP, Rey RA. Anti-Müllerian hormone and Sertoli cell function in paediatric male hypogonadism. Horm Res Paediatr. 2010;73:81-92

39. Bin-Abbas B, Conte F, Grumbach M, Kaplan S. Congenital hypogonadotropic hypogonadism and micropenis: Effect of testosterone treatment on adult penile size--Why sex reversal is not indicated. J Pediatr. 1999;134:579-83.

40. Lawaetz JG, Hagen CP, Mieritz MG, et al. Evaluation of 451 Danish boys with delayed puberty: diagnostic use of a new puberty nomogram and effects of oral testosterone therapy. J Clin Endocrinol Metab. 2015:100:1376-85.

41. Chioma L, Papucci G, Fintini D, Cappa M. Use of testosterone gel compared to intramuscular formulation for puberty induction in males with constitutional delay of growth and puberty: a preliminary study. J Endocrinol Invest. 2018;41:259-63.

42. Contreras MF, Raisingani M, Prasad K, et al. Transderma testosterone gel for induction and continuation of puberty in adolescent boys with hepatic dysfunction. J Pediatr Endocrinol Metab. 2017;30:105-9.

43. Ulloa-Aguirre A, Lira-Albarran S. Clinical applications of gonadotropins in the male. Prog Mol Biol Transl SCi. 2016;143:121-74.

44. Main KM, Schmidt IM, Skakkebæk NE. A possible role for reproductive hormones in newborn boys: progressive hypogonadism without the postnatal testosterone peak J Clin Endocrinol Metab. 2000:85:4905-7.

45. Main KM, Schmidt IM, Toppari J, Skakkebæk NE. Early postnatal treatment of hypogonadotropic hypogonadism with recombinant human FSH and LH. Eur J Endocrinol. 2002:146:75-9.

46. Stoupa A, Samara-Boustani D, Flechtner I, et al. Efficacy and safety of continuous subcutaneous infusion of recombinant human gonadotropins for congenital micropenis during early infancy. Horm Res Paediatr. 2017;87:103-10.

47. Bouvattier C, Maione L, Bouligand J, et al. Neonata gonadotropin therapy in male congenital hypogonadotropic hypogonadism. Nat Rev Endocrinol. 2012;8:172-82.

48. Rohayem J, Hauffa BP, Zacharin M, et al. Testicular growth and spermatogenesis: new goals for pubertal hormone replacement in boys with hypogonadotropic hypogonadism? -a multicentre prospective study of hCG/rFSH treatment outcomes during adolescence. Clin Endocrinol (Oxf). 2017;86:75-87.

49 Zacharin M, Sabin MA, Nair W, Dabadghao P. Addition of recombinant follicle-stimulating hormone to human chorionic gonadotropin treatment in adolescents and young adults with hypogonadotropic hypogonadism promotes normal testicular growth and may promote early spermatogenesis. Fertil Steril. 2012;98:836-42

50. Raivio T, Wikström AM, Dunkel L. Treatment of gonadotropindeficient boys with recombinant human FSH: long-term observation and outcome. Eur J Endocrinol. 2007;156:105-11

51. Dwyer AA, Sykiotis GP, Hayes FJ, et al. Trial of recombinant follicle-stimulating hormone pretreatment for GnRH-induced fertility in patients with congenital hypogonadotropic hypogonadism. J Clin Endocrinol Metab. 2013'98'E1790-5. 